\title{
MEMPERTAHANKAN TRADISI PACU JAWI: ETNOGRAFI TENTANG PENGETAHUAN DAN PRAKTEK MEMELIHARA SAPI PACUAN DI NAGARI III KOTO, KABUPATEN TANAH DATAR, SUMATERA BARAT
}

\author{
Adilla Pratama 1, Abdullah Akhyar Nasution ${ }^{1}$ \\ ${ }^{1}$ Program Studi Antropologi, Fakultas Ilmu Sosial dan Ilmu Politik, Universitas \\ Malikussaleh
}

Korespondensi: adielpratama96@gmail.com

\begin{abstract}
Abstrak: Penelitian ini berjudul Mempertahankan Tradisi Pacu Jawi (Etnografi Tentang Pengetahuan Dan Praktek Memelihara Sapi Pacuan Di Nagari III Koto, Kabupaten Tanah Datar, Sumatera Barat). Penelitian ini mengkaji tentang nilainilai yang terkandung dalam Pacu Jawi bagi masyarakat dan untuk mengetahui sistem pengetahuan dan praktek perawatan Jawi Pacuan. Metode dalam penelitian ini penulis menggunakan metodelogi penelitian Kualitatif dengan pendekatan Etnografi. Teknik pengumpulan data observasi partisipatif, wawancara tak terstruktur, dan studi dokumen. hasil penelitian menunjukan nilai-nilai yang terdapat dalam Pacuan Jawi di masyarakat Padang Luar ada nilai kerjasama ini tercermin dalam pacu jawi dimana masyarakat dan panitia bekerjasama agar acara pacu jawi dapat berjalan dengan baik, hal ini dapat dilihat dalam kerja sama masyarakat dan panitia untuk mempersiapkan lokasi untuk pacuan jawi tersebut. Disini masyarakat dan panitia menyiapkan tenda dan mencari air untuk mengaliri sawah yang akan dipakai untuk pacuan jawi, kerjasama antar pemilik Jawi dan pemilik jawi lainnya serta seorang joki dalam memasang Tajak kepada Jawi tersebut, kerjasama antar penonton dapat juga kita lihat untuk saling menjaga keamanan dan kenyamanan saat menonton Pacuan Jawi. Sistem pengetahuan dan perawatan jawi pacuan yang dimiliki masyarakat Padang Luar, khususnya peternak jawi pacuan mereka membuat kandang yang agak berbeda dari jawi ternak lainnya, kalau jawi pacuan kandangnya biasa dilantai menggunakan bambu, bambu ini disusun dengan serapi-rapinya agar Jawi tersebut nyaman dan tidak terkena penyakit Rematik. Perawatan Jawi Pacuan ini tidak jauh beda dibandingkan Jawi ternak lainnya, yang membedakannya Jawi Pacuan ini harus dilatih dan diberi makanan tambahan untuk menunjang dan membuat Jawi berkembang begitu cepat.
\end{abstract}

Kata Kunci : Pacuan Jawi, Etnografi, Perawatan Jawi Pacuan 


\section{A. Pendahuluan}

Kabupaten Tanah Datar Merupakan wilayah yang terletak di Provinsi Sumatra Barat, Dimana kondisi Adat masih kental di dalamnya sehingga Pacu Jawi (balapan sapi) sebagai tradisi adat menjadi daya tarik tersendiri. Pacu Jawi sendiri adalah Balapan Sapi khas Minangkabau tepatnya di Kabupaten Tanah Datar, Sumatera Barat. Balapan Sapi ini biasanya dilakukan habis panen padi. Balapan sapi ini dilakukan atas dasar rasa syukur atas hasil bumi yang melimpah.

Pacu Jawi ini dilakukan di 4 (Empat) Kecamatan yaitu, Kecamatan Limo Kaum, Kecamatan Rambatan, Kecamatan Pariangan, dan Kecamatan Sungai Tarab. Pacu Jawi (Balapan Sapi) ini juga menjadi Antraksi Budaya yang mengundang para Wisatawan Lokal maupun Manca Negara. Manfaat dari Pacu Jawi (Balapan Sapi) adalah sebagai wadah untuk meningkatkan harga jual Sapi, kemudian sebagai wadah untuk meningkatkan kesehatan Jawi (Sapi). Acara Pacu Jawi (Balapan Sapi) menjadi sarana hiburan bagi masyarakat dan menjadi Tradisi Adat di tengahtengah masyarakat.

Pacu berarti lomba kecepatan, Jawi sendiri adalah maksudnya Sapi atau Lembu. Di Sumatera Barat sapi biasa disebut dengan Jawi. Kegiatan Pacu Jawi merupakan acara permainan tradisional anak Nagari (Desa) yang lahir dan berkembang di Kabupaten Tanah Datar, Provinsi Sumatera Barat. Kegiatan ini hanya dapat ditemukan di Kabupaten Tanah Datar. Di Kabupaten Tanah Datar kegiatan ini ditemukan hanya pada empat kecamatan, yaitu Kecamatan Pariangan, Kecamatan Rambatan, Kecamatan Limo Kaum dan Kecamatan Sungai Tarab.

Kegiatan Pacu Jawi telah ada sejak ratusan tahun yang lalu dan menjadi sarana hiburan yang ditunggu-tunggu oleh masyarakat setempat. Pada kegiatan ini juga dipadukan dengan tradisi masyarakat berupa arak-arakan (pawai) pembawa dulang atau jamba yang berisi makanan dan arak-arakan Jawi-Jawi terbaik yang didandani dengan asesories berupa suntiang (sunting) serta pakaian. Biasanya acara tradisi ini diselenggarakan pada minggu ke-IV atau pada waktu penutupan Pacu Jawi dan menjadi perhelatan yang besar di daerah itu. Pada waktu itu juga diadakan prosesi adat oleh para tetua adat serta berbagai permainan seni budaya tradisional. 
Di arena Pacu Jawi juga bertumbuhan warung nasi, kopi daun, dan makanan khas Minangkabau Lainnya. Para pedagang kaki lima serta arena permainan anakanak sehingga lokasi itu terlihat seperti pasar. Pada waktu itulah masyarakat bergembira ria menyaksikan Jawi-Jawi kesayangan mereka berpacu, dan setelah itu mereka makan di warung-warung dengan makanan spesifik gulai kambing, Sate, Gorengan dan kopi kawa daun.

Pelaksanaan alek Pacu Jawi di Kabupaten Tanah Datar dilaksanakan secara bergiliran pada empat kecamatan. Satu kali putaran lomba biasanya empat minggu, hari yang dilakukan setiap hari Sabtu dan Minggu. Acara dilakukan di sawah milik masyarakat setelah selesai masa panen dan tempatnya tidak tetap pada satu lokasi saja. Bila kegiatan diadakan pada satu kecamatan maka peserta dari kecamatan lain akan berdatangan. Dalam satu masa perlombaan, jumlah Jawi yang berpacu mencapai 500 hingga 800 ekor.

Pacu Jawi diikuti oleh Jawi secara berpasangan yang dikendalikan oleh seorang anak joki yang berpegangan pada tangkai bajak. Anak joki dengan tidak memakai alas kaki ikut berlari bersama Jawinya di dalam sawah yang penuh lumpur dan air. Acaranya berlangsung mulai pukul sepuluh pagi hingga pukul lima sore. Pada waktu perlombaan berlangsung kadang kala juga terjadi transaksi jual beli Jawi oleh para pedagang dan pemilik Jawi. Biasanya Jawi yang telah sering memenangkan lomba akan naik harganya hingga dua kali lipat. Jawi pemenang itu akan menjadi kebanggaan bagi pemiliknya dan diincar oleh banyak orang.

Banyak orang yang belum tahu bagaimana cara penilaian Jawi terbaik yang menjadi pemenangnya. Teknis penilaian inipun penuh filosofi dan nilai-nilai yang baik. Adapun Jawi terbaik adalah Jawi yang dapat berjalan lurus tidak miring dan tidak melenceng ke mana-mana. Dan akan lebih baik lagi apabila Jawi tersebut dapat menuntun temannya berjalan lurus. Berarti Jawi itu sehat dan tubuhnya kokoh kuat. Biasanya dalam satu perlombaan akan terlihat Jawi yang berjalan lurus dan yang tidak, bahkan ada yang sampai masuk ke sawah lain. Jadi yang dinilai bukan hanya kencang larinya dan bukan bentuk struktur tubuhnya saja. Filosofinya Jawi saja harus berjalan lurus apalagi manusia. Dan manusia yang bisa berjalan lurus tentu akan tinggi nilainya, itulah pemenangnya.

Beberapa manfaat dari pelaksanaan Pacu Jawi adalah : 
1. Sebagai wadah untuk meningkatkan harga jual Jawi sehingga dapat

2. meningkatkan perekonomian peternak. Kemunian juga sebagai media untuk meningkatkan kesehatan Jawi karena Jawinya akan sehat setelah berpacu.

3. Pada acara Pacu Jawi banyak bermunculan para pedagang sehingga meningkatkan perputaran roda ekonomi yang dapat pula meningkatkan perekonomian masyarakat.

4. Acara Pacu Jawi menjadi sarana sosialisasi dan hiburan bagi masyarakat yang selalu ditunggu-tunggu.

5. Sebagai alek tradisi masyarakat dimana akan terjadi prosesi adat sebagai aktualisasi nilai-nilai adat di tengah-tengah masyarakat.

Pemerintah Kabupaten Tanah Datar secara konsisten membina dan mempertahankan kegiatan Pacu Jawi (balapan sapi) ini sesuai tradisi dan kebiasaan masyarakat. Pemerintah lebih banyak memfasilitasi ataupun membantu mengemas acara ini menjadi lebih baik sehingga bisa dipromosikan dan dijual kepada para wisatawan nusantara dan mancanegara. Sebagai organisasi pengelolanya pada masyarakat sudah ada PORWI (Persatuan Olah Raga Pacu Jawi) yang ada pada tingkat Kabupaten, Kecamatan hingga Nagari (Desa). Porwi inilah yang mengkordinir jadwal pelaksanaan secara bergiliran.

Kabupaten Tanah Datar dengan ibukotanya Batusangkar adalah salah satu dari 19 Kabupaten atau Kota di Propinsi Sumatera Barat. Kabupaten Tanah Datar disebut juga dengan Luhak Nan Tuo atau daerah tertua karena dari sinilah asal usul etnis dan budaya Minangkabau, yaitu tepatnya dari Nagari Tuo Pariangan. Sedangkan Batusangkar dikenal sebagai Kota Budaya karena di kota ini sangat banyak peninggalan budaya Minangkabau. Batusangkar juga dikenal sebagai pusat Kerajaan Pagaruyung dengan terdapatnya Istano Basa Pagaruyung dengan berbagai macam peninggalan bersejarah.

\section{B. Metode Penelitian}

Lokasi penelitian dilakukan di Nagari III Koto, Kecamatan Rambatan, Kabupaten Tanah Datar, Provinsi Sumatera Barat. Pemilihan lokasi ini sebagai Daerah Penelitian Dikarenakan berada tepat di Lokasi Pacu Jawi (Balapan Sapi). 
Lokasi Pacu Jawi (balapan sapi) hanya ada di Kecamatan Sungai Tarab, Pariangan, Rambatan dan Limo Kaum. Pacu jawi ini hanya ada di Kabupaten Tanah Datar, Sumatera Barat. Selain itu Tradisi Pacu Jawi (Balapan Sapi) juga merupakan daya Tarik wisatawan luar untuk datang ke Kabupaten Tanah Datar, Sumatra Barat. Pacu jawi ini jugu merupakan tradisi yang dilestarikan yang merupakan aktualisasi nilai-nilai adat di tengtah-tengah masyarakat.

\section{Kajian Teoretis}

Ethnography berarti "pelukisan tentang bangsa-bangsa". Istilah ini di pakai umum di Eropa Barat untuk menyebut bahan keterangan yang termasuk dalam keterangan-keterangan tentang masyarakat dan kebudayaan suku bangsa di luar Eropa, serta segala metode untuk mengumpulkan dan mengumumkan bahan itu. Sampai sekarang istilah itu masih lazim dipakai untuk menyebut bagian dari ilmu antropologi yang bersifat deskriptif (pengantar ilmu Antropologi, Prof. Dr. Koentjaraningrat 2009:9).

Etnografi berasal dari kata ethno (bangsa) dan graphy (menguraikan atau menggambarkan). Etnografi merupakan ragam pemaparan penelitian budaya untuk memahami cara orang-orang berinteraksi dan bekerja sama melalui fenomena teramati dalam kehidupan sehari-hari (Endraswara, 2006:50).

Etnografi ditinjau secara harfiah, berarti tulisan atau laporan tentang suatu suku bangsa yang ditulis oleh seorang antropolis hasil penelitian lapangan (field work) selama sekian bulan atau sekian tahun. Etnografi merupakan suatu bangunan pengetahuan yang meliputi teknik penelitian, teori etnografis dan berbagai macam deskripsi kebudayaan. Etnografi bermakna untuk membangun pengertian yang sistematikik mengenai semua kebudayaan manusia dari perspektif orang yang telah mempelajari kebudayaan itu (Spradley, 2006:13).

Penelitian etnografi adalah kegiatan pengumpulan bahan keterangan atau data yang dilakukan secara sistematik mengenai cara hidup serta berbagai aktivitas sosial dan berbagai benda kebudayaan dari suatu masyarakat. Berbagai peristiwa dan kejadian unik dari komunitas budaya akan menarik perhatian peneliti etnografi (Endraswara, 2006:50).

Penelitian antropologis untuk menghasilkan laporan tersebut begitu khas, sehingga kemudian istilah etnografi juga digunakan untuk mengacu pada metode 
penelitian untuk menghasilkan laporan tersebut. Belajar tentang etnografi berarti belajar tentang jantungnya dari ilmu antropologi, khususnya antropologi sosial.

Malinowsky (dalam Spadley, 2006:3-4) menyebutkan bahwa tujuan etnografi adalah "memahami sudut pandang penduduk asli, hubungan dengan kehidupan, untuk mendapatkan pandangan mengenai duniawi". Oleh karena itu, penelitian etnografi melibatkan aktifitas belajar mengenai dunia orang yang telah belajar, mendengar, berbicara, berfikir, dan bertindak dengan cara berbeda. Jadi etnografi tidak hanya mempelajari masyarakat, tetapi lebih dari itu, etnografi belajar dari masyarakat.

Pacu Jawi (balapan sapi) merupakan pamenan (permainan yang sifatnya menghibur dan menyampaikan nilai-nilai) anak Nagari selepas panen padi berupa memacu sepasang sapi di sawah yang berair dan berlumpur di Kabupaten Tanah Datar. Pacu berarti lomba kecepatan dan Jawi maksudnya sapi atau lembu, di Sumatra Barat sapi bisa disebut dengan Jawi. Sepasang sapi yang telah dipasangkan bingkai bajak (terbuat dari kayu atau bambu yang digunakan untuk membajak sawah) di pacu oleh seorang joki dengan berpijak di kedua ujung bingkai bajak tersebut sambil memegang kedua ekor sapi. Penilaiaan sapi yang bagus dan bernilai tinggi adalah sapi yang mampu berlari lurus dengan cepat dan beriringan, ditandai dengan besarnya lumpur yang bertebrangan. Sebagai suatu pamenan kegiatan Pacu Jawi bersifat menghibur dan menyampaikan nilai-nilai. Dalam hal ini nilai yang ingin di sampaikan adalah luruih (lurus). Filosofi yang berkembang sapi saja bisa berjalan lurus apalagi manusia dan manusia yang bisa berjalan lurus akan tinggi nilainya (lebih dihargai).

Kegiatan Pacu Jawi (balapan sapi) sudah menjadi tradisi masyarakat semenjak ratusan tahun lalu, di selenggarakan secara bergiliran di 4 (empat) Kecamatan yaitu: Kecamatan Sungai Tarab, Kecamatan Pariangan, Kecamatan Lima Kaum, dan Kecamatan Rambatan. Kegiatan ini biasanya dilaksanakan setiap hari Sabtu selama 4 kali berturut-turut. Minggu ke empat adalah acara puncak berupa penutupan yang dihadiri niniak mamak dan pertunjukan kesenian tradisi. Dalam sistem Nagari berlaku kepemimpinan tigo tungku sajarang (tiga tungku sejarang) yaitu Penghulu, ulama dan cerdik pandai yang secara bersama-sama memimpin masyarakat. Kepemimpinan ini berada dalam kerapatan Adat Nagari 
(KAN) yang merupakan lembaga kerapatan niniak mamak lembaga tertinggi dalam penyelenggaraan Adat di Nagari. KAN dalam Pacu Jawi berperan mempersatukan masyarakat dan menjaga agar tidak terjadi perselisihan antara anak kemenakan (pemuda di Nagari) (Suzanti, 2014).

Pacu Jawi merupakan tradisi yang sudah ada semenjak ratusan tahun yang lalu. Asal mula Pacu Jawi dimulai di sebuah Nagari yaitu Nagari Tuo Pariangan Kabupaten Tanah Datar. Pacu Jawi merupakan upaya bagi para petani pada waktu dulu untuk menemukan cara membajak sawah yang baik dan benar, karena belum ada alat atau mesi bajak seperti pada saat sekarang. Penemu Pacu Jawi adalah Datuak Tantejo Gurhano merupakan orang tertua yang arif dan bijaksana. Datuak Tantejo Gurhano mencari cara agar sawahnya menjadi subur dan mudah di tanami. Caranya adalah dengan membajak sawah menggunakan Jawi (sapi). Dalam membajak Datuak Tantejo Gurhano mengajak kemenakannya (keponakannya) sebagai joki yang akan mengendalikan Jawi dan dua orang lagi untuk memegang dan mengarahkan Jawi. Tujuan menambah dua orang tadi adalah sebagai pemegang tali Jawi (sapi) yang terdapat di mulut Jawi. Membajak menggunakan Jawi akan membuat tanah menjadi gembur dan subur, tanah yang subur disebabkan oleh kotoran Jawi. Dengan tanah yang gembur dan subur membuat hasil panen padi berlimpah. Keberhasilan Datuak Tantejo Gurhano dalam membajak sawah tersebar ke lingkungan sekitar dan daerah lain, sehingga masyarakat ingin mengikuti metode yang digunakan oleh Datuak Tantejo Gurhano dalam membajak sawah agar mendapat tanah yang subur dan gembur serta panen yang melimpah (Djam'an Satori dan Aan Komariah, 2009).

\section{Pembahasan}

\section{Sejarah dan Asal Usul Nagari III Koto}

Menggali sejarah nenek moyang merupakan panggilan moral dan kewajiban bagi setiap orang. Tanpa mengetahui orang tua dan nenek moyang biasa dikategorikan banyak orang dengan anak jadah atau haram. Istilah untuk lareh nan Panjang "Koto Piliang Indak, Bodi Caniago Antah" merupakan tantangan yang harus dijawab dengan bukti sejarah. Kita harus siap mambangkik (membangkit) batang tarandam (terendam) tentang asal usul nenek moyang kita tentunya. 
Lareh Nan Panjang adalah sosok juru pendamai dikala perselisihan antara Inyiak (nenek) Koto Piliang dan Bodi Caniago, pertanda bahwa nenek moyang kita adalah yang tertua di Minangkabau. Terbitnya penulisan buku sejarah Minangkabau berasal dari Luhak 50 Kota yang dibiayai penulisan dan penerbitannya oleh dana DPRD Sumatera Barat, menggelitik motivasi kita untuk berjuang dan berkorban membuktikan bahwa Lareh Nan Panjanglah asal muasal orang Minangkabau.

Tidurnya kita sebagai pewaris Lareh Nan Panjang bagaikan tidurnya ashabul kahfi, tidurnya sampai beratus tahun. Sekarang masanya cicit beliau membuktikan dengan dilengkapi Prasasti dan aset budaya serta sejarah yang masih utuh, agar Pemerintah Sumatera Barat dan masyarakat Minangkabau mengetahuinya. Kita lanjutkan sejarahnya untuk "Nagari III Koto".

Nagari III Koto dikenal sebagai salah satu destinasi wisata yang cukup digandrungi. Bahkan saking terkenalnya, bukan hanya pendatang namun juga warga Kota Batusangkar sendiri banyak yang mendatangi Nagari III koto ini untuk pergi berliburan.

Jumlah penduduk Nagari III Koto tahun 2017 tercatat sebanyak 6.872 jiwa. Sebagaimana tabel di bawah ini:

Tabel. 1.

Luas wilayah dan Jumlah Penduduk Berdasarkan Jorong Tahun 2017

\begin{tabular}{|c|c|c|c|c|c|}
\hline \multirow{2}{*}{ No } & \multirow{2}{*}{ Jorong } & \multirow{2}{*}{$\begin{array}{c}\text { Luas } \\
\text { Wilayah }\end{array}$} & $\begin{array}{c}\text { Laki- } \\
\text { laki } \\
\text { (jiwa) }\end{array}$ & $\begin{array}{c}\text { Perempuan } \\
\text { (jiwa) }\end{array}$ & $\begin{array}{c}\text { Jumlah } \\
\text { (jiwa) }\end{array}$ \\
\cline { 4 - 6 } & & & $\mathbf{( 4 )}$ & $\mathbf{( 5 )}$ & $\mathbf{( 6 )}$ \\
\hline \hline $\mathbf{1})$ & $\mathbf{( 2 )}$ & $\mathbf{3}$ & 487 & 462 & 949 \\
\hline \hline 1 & Kalumpang & 2,18 & 291 & 268 & 559 \\
\hline 2 & Gantiang & 2,22 & 291 & 119 & 273 \\
\hline 3 & Guguak Jambu & 1,54 & 154 & 250 & 497 \\
\hline 4 & Aur Serumpun & 2.34 & 247 & 254 & 544 \\
\hline 5 & Siturah & 2,12 & 290 & 136 & 283 \\
\hline 6 & Panta & 1,76 & 147 & & \\
\hline
\end{tabular}


Aceh Anthropological Journal, Vol. 4, No. 1 , hlm: 90-109, April 2020

\begin{tabular}{|c|c|c|c|c|c|}
\hline 7 & Bonai & 5.54 & 347 & 343 & 690 \\
\hline 8 & Pasir Jaya & 2,13 & 256 & 226 & 482 \\
\hline 9 & Galogandang & 4,03 & 942 & 887 & 1.829 \\
\hline 10 & Turawan & 1,90 & 407 & 396 & 803 \\
\hline & JUMLAH & $\mathbf{2 5 , 7 6}$ & $\mathbf{3 . 5 6 8}$ & $\mathbf{3 . 3 4 1}$ & $\mathbf{6 . 9 0 9}$ \\
\hline
\end{tabular}

Sumber : Badan Pusat Statistik (BPS) Kabupaten Tanah Datar

Dari data diatas menunjukkan bahwa jumblah penduduk di tahun 2017 sebesar 6.909 jiwa berdasarkan klasifikasi sesuai dengan jenis kelamin dengan perbandingan yang seimbang antara jumblah penduduk laki-laki dan perempuan. Dari sepuluh Jorong yang ada di Nagari III Koto penduduk yang paling banyak menetap di Jorong Galogandang dengan 1.829 jiwa, laki-laki 942 jiwa dan perempuan 887 jiwa.

\section{Sejarah dan Tradisi Perkembangan Pacu Jawi}

Asal mula Pacu Jawi diadakan oleh para petani dan masyarakat di Di kabupaten Tanah Datar guna mengisi waktu luang sesudah waktu panen. Pacu berarti lomba kecepatan dan Jawi maksudnya sapi atau lembu. Di Sumatera Barat sapi biasa disebut Jawi. Kegiatan Pacu Jawi merupakan acara permainan Tradisional anak Nagari yang lahir dan berkembang di Kabupaten Tanah Datar, Provinsi Sumatera Barat. Kegiatan ini hanya ada di Kabupaten Tanah Datar. Di Kabupaten Tanah Datar pun hanya pada empat Kecamatan, yaitu Kecamatan Pariangan, Kecamatan Rambatan, Kecamatan Limo Kaum dan Kecamatan Sungai Tarab. Kegiatana Pacu Jawi sudah ada sejak ratusan tahun yang lalu dan mejadi sarana hiburan yang ditunggu-tunggu oleh masyarakat setempat.

Pada kegiatan ini juga dipadukan dengan Tradisi masyarakat berupa arakarakan pembawa dulang atau jamba yang berisi makanan dan arak-arakan Jawi terbaik yang didandani denagan aksesoris berupa sunting serta pakaian. Biasanya acara Tradisi ini diselenggarakan pada minggu ke-IV atau pada waktu penutupan Pacu Jawi dan menjadi perhelatan yang besar di daerah itu.Pada waktu itu juga diadakan prosesi Adat oleh para ketua Adat serta berbagai permainan seni budaya Tradisional. pada waktu itulah masyarakat bergembira ria menyaksikan Jawi-Jawi 
kesayangan mereka berPacu. Pelaksanaan Alek Pacu Jawi di Kabupaten Tanah Datar dilaksanakan bergiliran pada empat kecamatan. Adapun acara Pacu Jawi dilakasanakan di sawah milik masyarakat setelah selesai masa panen, untuk penempatan Pacu Jawi tidak dilaksanakan hanya di satu tempat saja. Bila didakan di satu Kecamatan maka peserta dari Kecamatan lain juga ikut bergabung.

Dalam satu masa perlombaan, jumlah Jawi yang berPacu mencapai 500 hingga 800 ekor Jawi. Pacu Jawi diikuti oleh Jawi secara berpasangan yang dikendalikan oleh seorang anak joki yang berpegang pada tangkai bajak. Anak joki dengan tidak memakai alas kaki ikut berlari bersama Jawinya di dalam sawah yang penuh lumpur dan air. Acara berlangsung dimulai dari jam sepuluh pagi hingga selesai pada pukul lima sore. Pada waktu perlombaan berlangsung kadang kala ada proses transaksi jual beli oleh para pedagang dan pemilik Jawi. Biasanya, Jawi yang telah sering memenangkan lomba akan naik harga hingga dua kali lipat. Banyak orang yang belum mengerti bagaimana cara penilaian Jawi terbaik yang menjadi pemenangnnya. Teknis penilaian inipun penuh filosofi dan nilai-nilai yang baik. Adapun Jawi terbaik adalah Jawi yang dapat berjalan lurus tidak miring dan tidak melenceng ke mana-mana. Akan lebih baik lagi apabila Jawi tersebut dapat menuntun temannya berjalan lurus. Berarti Jawi itu sehat dan tubuhnya kokoh kuat. Biasnya dalam satu perlombaan akan terlihat Jawi yang berjalan lurus dan tidak, bahkan ada yang sampai masuk ke sawah lain. Jadi yang dinilai bukan hanya Jawi yang kencang lairnya dan bukan bentuk struktur tubuhnya saja.Filosofinya adalah Jawi saja harus berjalan lurus apalagi manusia. Manusia yang berjalan lurus tentu akan tinggi nilainya, itulah pemenangnya.

Beberapa manfaat dari pelaksanan Alek Pacu Jawi adalah :

1. Sebagai wadah untuk meningkatkan harga jual Jawi sehingga dapat meningkatkan perekonomian peternak. Kemudian juga sebagai media untuk meningkatkan kesehatan Jawi karena Jawinya akan sehat setelah berPacu.

2. Pada acara Pacu Jawi banyak bermunculan para pedagang sehingga meningkatkan perputaran roda ekonomi yang dapat pula meningkatkan perekonomian masyarakat. Disini masyarakat menjual berbagai makanan 
dan minuman yang Khas dari Ranah Minang seperti Kawa Daun, Sate, Nasi Kapau, dan berbagai macam jenis makanan lainnya.

3. Acara Pacu Jawi menjadi sarana sosialisasi dan hiburan bagi masyarakat yang ditunggu-tunggu dikarenakan disini juga menjadi ajang silaturahmi masyarakat antar Nagari.

4. Sebagai Alek Tradisi masyarakat dimana akan terjadi Tradisi masyarakat dimana akan terjadi prosesi Adat sebagai aktualisasi nilai-nilai Adat ditengah-tengah masyarakat.

Adapun nilai-nilai yang terkandung dalam Pacuan Jawi di masyarakat Padang luar, Nagari III Koto, Kabupaten Tanah Datar dapat di lihat langsung dari apa yang dilakukan masyarakat Nagari III Koto :

1. Nilai kerjasama

Nilai kerjasama ini tercermin dalam Pacu Jawi Dimana masyarakat dan panitia bekerjasama agar acara Pacu Jawi dapat berjalan dengan baik, hal ini dapat kita lihat dalam kerja sama masyarakat dan panitia untuk mempersiapkan lokasi untuk Pacuan Jawi tersebut. Disini masyarakat dan panitia menyiapkan tenda dan mencari air untuk mengaliri sawah yang akan di pakai untuk Pacuan Jawi. Lalu kerjasama antara pemilik sapid an pemilik sapi lainnya serta saat seorang joki memasak tajak pada sapi Pacuannya mereka bekerjasama dengan pemilik sapi untuk memasang tajak kepada Jawi tersebut. Kerjasama antara penonton dapat uga kita lihat untuk saling menjaga keamanan dan kenyamanan saat menonton Pacuan Jawi. Nilai kerjasama dalam Pacu Jawi dapat dilihat dari dari semua masyarakat, panitia, pemilik sapi, joki dan masyarakat.

2. Nilai ketertiban

Nilai ketertiban tercermin pada saat peserta dengan sabar menunggu giliran sapi-sapi Pacuan mereka untuk berPacu. Dalam perlombaan Pacu Jawi ini sapi yang berlomba hanya sepasang-sepasang saja, sehingga peserta yang lain harus menunggu giliran dengan tertib dan sabar.

3. Nilai Seni

Nilai seni yang tercermin dalam Pacuan Jawi adalah permainan dari anak Nagari melakukan Tari Piring, Talempong, dan Aguang Bana. Kesenian 
Tradisional Minangkabau ini mengiringi Pacuan Jawi tersebut. Hal ini dapat dilihat pada saat music talempong mengiringi tarian piring dan pada saat Niniak mamak berdialog dengan menggunakan Petatah Petitih yang dialunkan sambil berdendang dengan kata-kata penuh makna.

4. Nilai Agama

Nilai agama yang tercermin dalam Pacuan Jawi ini adalah ungkapan rasa syukur masyarakat atas hasil panen yang mereka dapatkan. Masyarakat menyadari bahwa semua yang di dapat harus selalu di syukuri.

Para peternak Jawi Pacu di Nagari III Koto mereka bisa meningkatkan Nilai harga Jawi tersebut, hal ini juga berpengaruh kepada hidup mereka atau status mereka, dikarenakan semakin bagusnya Jawi mereka di Pacuan Jawi maka semakin tinggi pula harga Jawi mereka. Tingginya harga Jawi tersebut dapat juga meningkatkan status mereka di masyarakat, dikarenakan perekonomian mereka menjadi sangat baik.

\section{Setingan di Balik Layar Alek Pacu Jawi dan Eksistensi Nagari III Koto Sebagai Sentra Penyedia Jawi Pacu}

Alek Pacu Jawi yang berada di Padang Lua, Nagari III Koto, Kecamatan Rambatan, Kabupaten Tanah Datar merupakan salah satu dari sekian banyak Objek wisata yang ada di wilayah Kabupaten Tanah Datar. Letaknya yang tidak terlalu jauh dari pusat Kota Batusangkar yaitu sekitar $17 \mathrm{KM}$ dan akses jalan yang sudah sangat bagus sehingga ini akan memudahkan bagi wisatawan lokal maupun internasional untuk datang kesini.

Salah satu alasan bahwa wisatawan harus datang dan berkunjung ke Alek Pacu Jawi ini adalah Alek Pacu Jawi ini sangat unik dan hanya ada di Kabupaten Tanah Datar, sekaligus pemandangannya yang sangat indah dan dikelilingi oleh barisan pegunungan dan sawah yang terlihat bagaikan lukisan hijau di sekeliling Nagari III Koto.

Berikut ini ada beberapa tata cara pelaksanaan Tradisi Pacu Jawi Di Nagari III Koto pada halaman berikutnya. 
a. Tahap Persiapan

Pada tahap persiapan yang dilakukan pertama kali adalah mencari dan menentukan lokasi atau lahan kegiatan Pacu Jawi, mencari air dan mengaluskan laha untuk arena Раси Jawi. Sebelum kegiatan Рacu Jawi diselenggarakan masyarakat di Nagari III Koto akan melakukan gotong royong. Para masyarakat nantinya akan bergotong royong membersihkan lokasi dan melancarkan saluran air. Setelah selesai kegiatan Pacu Jawi masyarakat biasanya juga bergotong royong meratakan lumpur, sampah-sampah yang ada di sawah, membersihkan petakpetak sawah yang siap di pakai untuk Pacu Jawi agar sawah siap untuk untuk ditanam kembali oleh pemilik sawah tersebut.

b. Tahap Pelaksanaan

Acara pembukaan dalam Tradisi Pacu Jawi sebelum acara dimulai maka acara akan dibuka terlebih dahulu oleh Kepala Dinas atau pemerintah Daerah dan juga dihadiri oleh tokoh-tokoh Adat. Pada acara pembukaan biasanya juga diiringi oleh musik Tradisinal seperti Talempong.

Kegiatan perlombaan Pacu Jawi dilaksanakan empat kali dalam satu bulan pada hari sabtu dan minggu saja. Yang mengatur jadwal kegiatan Pacu Jawi adalah PORWI (Persatuan Olahraga Pacu Jawi). PORWI merupakan organisasi yang mengatur tentang Jadwal Pacu Jawi. Setelah ditentukannya jadwal Pacu Jawi kemudian ketua PORWI akan memberitahukan kepada Dinas Kebudayaan, Pariwisata, Pemuda dan Olahraga Kabupaten Tanah Datar. Kemudian dari pada hal diatas Pemerintah akan melakukan Pembinaan, untuk memperkenalkan dan mempromosikan Pacu Jawi. Setelah jadwal ditentukan kemudian acara Pacu Jawi akan dilaksanakan. Acara Pacu Jawi dimulai pada pukul sepuluh pagi sampai dengan jam empat sore. Sebelum acara dimulai Arena Pacu Jawi sudah dipenuhi oleh penoton baik dari dalam koto ataupun luar kota. Sawaah tempat berlangsungnya Pacu Jawi digunakan sawah yang sudah siap panen, dengan panjang sawah sekitar seratus meter sampai seratus lima puluh meter dan lebar antara dua puluh lima sampai tiga puluh meter.

Sehari sebelum pertandingan sawah akan dialiri air, ini tujuannya agar sapi bisa berlari diatas lumpur yang tidak terlalu keras dan lunak. Pada saat lomba, Jawi secara berpasangan akan lari dari garis start sampai finis. Jawi dikendalikan oleh 
seseorang Joki yang berpegangan pada tangkaibajak, dengan tidak memakai alas kaki ikut berlari bersama kedua ekor Jawinya di dalam sawah yang penuh lumpur dan air. Joki bertugas menjaga keseimbangan kedua Sapi, agar sepasang Sapi tidak terpisah dan bisa berlari lurus sampai ke finish. Seseorang joki memiliki peran yang sangat penting dalam Pacu Jawi karena menjadi seorang Joki bukanlah perkara yang mudah, Joki harus bisa mengendalikan dua ekor Sapi sekaligus.

Dalam Tradisi Pacu Jawi ini cara penilaiaan dan menentukan juara berbeda dengan balapan sapi lainnya, Karena dalam Pacu Jawi ini tidak ada Juri Khusus. Masyarakat yang jadi penontonpun bisa menjadi Juri menilai Jawi yang bagus pada saat Jawi berlari di Area Pacuan. Cara untuk penilaian ini adalah Jawi harus berlari Lurus, tidak miring dan tidak melenceng keluar Arena dan dapat menuntun temannya untuk berjalan lurus sampai finish.

c. Tahap Penutupan

Tahap penutupan pada acara Tradisi Pacu Jawi lebih meriah dibandinkan acara acara pembukaan Pacu Jawi tersebut. Hal ini disebabkan Karena pada penutupan tidak hanya Jawi yang akan berPacu tetapi juga ada penampilan kesenian dari masyarakat. Pada tahap penutupan ini juga dihadiri oleh tokohtokoh masyarakat seperti Datuk, Angku Ampek, Malin, Sutan dan lain-lain. Pemerintah juga akan memanfaatkan acara ini untuk menyampaikan programprogram yang akan berjalan pada masyarakat.

Acara pada penutupan Tradisi Pacu Jawi ini ada Pawai atau arak-arakan. Acara penutupan ini sangat ditunggu-tunggu oleh penonton karena pada acara Pawai ini penonton dapat melihat sapi yang didandani dan diberi suntiang (Sunting). Bagi penonton yang pertama kali melihat sapi yang di dandani dan diberi sunting ini akan mejadi sangat menarik dan unik, karena hanya di Pacu Jawi inilah kita dapat melihat sapi yang didandani ini aka di arak bersama ibu-ibu yang mmembawa dulang yang dibungkus dengan kain yang bewarna-warni, Dulang ini berisi makanan Khas Daerah.

Penampilan kesenian Tradisional dari masyarakat Minangkabau dapat dilihat juga pada penutupan Tradisi Pacu Jawi ini.terdapat sebuah tenda kesenian tempat para seniman mempertunjukkan kepandaian mereka seperti Tari Piring, Talempong Pacik, dan Gendang. Pada penutupan Tradisi Pacu Jawi ini Niniak 
Mamak (Datuk) mereka akan menampilkan kepintaran mereka dalam berdialog, dengan menggunakan petatah petitih (Pepatah) yang dialunkan sambil berdendang dengan kata-kata penuhmakna. Di dalam pepatah ini digambarkan peranan Niniak Mamak (Datuk), Alin Ulama, Bundo Kanduang, Anak Muda dalam Nagari.

\section{Pengetahuan Jenis-Jenis Jawi Dan Termasuk Jawi Pacuan}

Masyarakat Peternak Sapi Pacu Nagari III Koto dan daerah-daerah penyuplai sapi Pacuan daerah lainnya mengetahui mana Sapi yang bagus di jadikan untuk sapi Pacuan. Ciri-ciri sapi Pacuan dapat kita ketahui dari dua jenis sapi yaitu Pertama bernama Jawi balang puntuang berarti apabila didahuluan manyipak (menendang), dikudiankan mananduak (menanduk) apabila didahulukan menyipak (menendang), apabila di kemudiankan menanduk, Dan sifat Jawi yang bagus adalah Jawi yang jalannya lurus tanpa dikendalikan. Sifat yang kedua yaitu Jawi sirah (merah), Jawi ini diibaratkan Jawi yang egois, dan dimanamana suka berbuat onar.

Para peternak Jawi Pacuan biasanya hanya membeli bibit Jawi Pacuan, peternak tidak ada yang membuat Jawi Pacu tersebut menjadi bibit. Peternak sapi Pacuan biasanya membeli langsung bibit itu di pasar ternak terdekat seperti di pasar ternak Cubadak. Untuk membeli bibit Jawi mana yang bagus dan bukan disini diperlukan juga keahlian untuk memilihnya. Keahlian yang diperlukan untuk memilih Jawi Pacuan yang bagus itu bisa dilihat dari Jawi tersebut dimulai dari warna Jawi, bentuk badan, pusar-pusar, telapak kaki, dan yang paling utama itu Jawi ini haruslah Jawi kampung, Peranakan Ongole (P0).

Para peternak Jawi Pacuan mereka menggunakan Jawi Peranakan Ongole (PO). Sapi PO yang dimaksud oleh para peternak adalah Sapi Ongole, Sapi Ongole adalah Hasil perkawinan antara sapi ongole dengan sapi jawa adalah sapi PO atau Sapi Peranakan Ongole (PO). Sapi PO terkenal sebagai sapi pedaging dan sapi pekerja, mempunyai kemampuan adaptasi yang tinggi terhadap perbedaan kondisi lingkungan, memiliki tenaga yang kuat dan aktivitas reproduksi induknya cepat kembali normal setelah beranak, jantannya memiliki kualitas semen yang baik. 
Ukuran tubuh besar dan bisa lebih tahan terhadap kepanasan, kehausan dan kelaparan, Serta dapat mengkondisikan diri dengan mengkonsumsi pakan berkualitas rendah sekalipun. Banyak dikembangbiakan oleh para peternak di Tanah Datar, Sumatera Barat. dengan demikian sapi ini juga dikenal dengan nama Sapi PO.

\section{Praktek Perawatan Jawi Pacuan}

Masyarakat Nagari III Koto khususnya peternak Jawi Pacuan mereka memberi makanan Jawi untuk menunjang agar pertumbuhannya lebih cepat, para peternak biasanya mengasih rumput, rumput yang dimaksud oleh peternak seperti rumput gajah. Rumput gajah ini diyakini para peternak lebih cepat untuk perkembangan Jawi Pacu dikarenakan banyak mengandung protein. Rumput gajah ini biasanya di tanam oleh para peternak di lereng bukit ataupun kebun. Selain makanan pangan para peternak juga memberi makanan non rumput seperti daun jagung, jahe, madu, telur ayam kampong, ataupun telur bebek. Semua bahan-bahan seperti jahe, madu, telur ayam kampung, telur bebek dicampurkan ke dalam satu tempat dan diolah menjadi ramuan untuk Jawi Pacuan. Bahan tersebut biasanya hanya digunakan sebelum atau sesudah latihan dan sebelum Pacu Jawi dimulai.

Masyarakat Nagari III Koto khususnya peternak Jawi Pacuan mereka membuat kandang yang agak berbeda dari Jawi ternak lainnya. Kalau Jawi Pacuan kandangnya biasanya di lantai menggunakan bambu, bambu ini disusun dengan serapi-rapinya agar Jawi tersebut nyaman dan tidak terkena penyakit rematik. Kalau Jawi ternak biasa para peternak tidak memperhatikan kandangnya apakah harus di lantai dengan bambu, di semen, atau tidak di lantai sama sekali. Disinilah yang membuat perbedaan kandang Jawi biasa dan Jawi Pacuan.

Perawatan Jawi Pacu ini tidak jauh beda dibandingkan Jawi ternak lainnya, yang membedakannya hanyalah Jawi Pacu ini harus dilatih dan diberi makanan tambahan untuk menunjang dan membuat Jawi berkembang begitu cepat. Makanan untuk menunjang pertumbuhannya supaya cepat para peternak menyakini memberi rumput gajah dan daun jagung. Para peternak juga memberi makanan lainnya untuk menambah stamina dan supaya nafsu makannya bertambah dengan membuat ramuan seperti telur bebek atau telur ayam 
kampung, jahe, madu, gula merah. Semua bahan ini akan dicampurkan ke dalam satu tempat lalu jadilah ramuan untuk menambah stamina Jawi tersebut.

Untuk latihan Jawi Pacu ini biasanya dilatih dua atau tiga kali dalam satu minggu. Pertama kali sapi ini dilatih satu persatu disini dibutuhkan kesabaran untuk melatihnya. Latihan pertama kalinya adalah latihan kesabaran disini Jawi akan dibawa ke sawah untuk bisa berlari lurus Sampai ujung pematang sawah, Jawi ini biasanya dibiarkan dulu untuk mengenal bagaimana lintasan yang akan di lewatinya. Biasanya para peternak juga membawa Jawi ini langsung ke tempat tradisi Pacu Jawi guna untuk menigkatkat mental Jawi tersebut.

Disini para peternak memiliki cara untuk membuat Jawi selalu sehat. Para peternak biasanya memberikan perhatian lebih kepada Jawi Pacuannya, biasanya sehabis latihan dan tanding Jawi-Jawi tersebut akan di beri ramuan khusus supaya kondisi Jawi tersebut tetap kuat dan sehat, ramaun yang dimaksud adalah ramuan seperti telur bebek atau telur ayam kampung, jahe, madu, gula merah. Semua bahan-bahan ini dicampur dan di beri kepada Jawi tersebut.

Selain memberi ramuan para peternak biasanya memandikan Jawi tersebut di pinggir sawah atau sungai, sehabis dimandikan para peternak menjemur dan mengusuk Jawi tersebut. Tujuan menjemur Jawi tersebut agar tidak kedinginan sehabis dimandikan, mengusuk Jawi tersebut sehabis dimandikan di pinggiran sawah tujuannya agar otot-otot Jawi tersebut lemas dan tidak kaku.

Biasanya Jawi Pacu ini disuntik oleh mantari (dokter hewan) setiap satu bulan sekali supaya tidak terjangkit penyakit, tujuan menyuntik ini juga untuk menghilangkan bakteri jahat yang ada pada Jawi tersebut.

Yang terlibat langsung dalam perawatan Jawi Pacuan ini adalah para peternak, selain itu disini yang terlibat dalam perawatan Jawi Pacu itu adalah mantari (dokter hewan) adapun hal-hal lain yang terlibat dalam proses perawatan Jawi Pacu ini adalah dukun Jawi, dukun Jawi ini biasanya membuat ritual sebelum latihan dan tanding. Ritual yang dilakukan oleh dukun tersebut adalah mendo,akan Jawi tersebut. 


\section{E. Kesimpulan}

Berdasarkan hasil penelitian tentang "Mempertahankan Tradisi Pacu Jawi (Etnografi Tentang Pengetahuan Dan Praktek Memelihara Sapi Pacuan Di Nagari III Koto, Kabupaten Tanah Datar, Sumatera Barat)", maka penulis mengambil beberapa kesimpulan sebagai berikut.

Nilai-nilai yang terdapat dalam pacuan jawi di masyarakat Padang Luar, Kabupaten Tanah Datar. Nilai kerjasama ini tercermin dalam Pacu jawi Dimana masyarakat dan panitia bekerjasama agar acara pacu jawi dapat berjalan dengan baik, hal ini dapat kita lihat dalam kerja sama masyarakat dan panitia untuk mempersiapkan lokasi untuk pacuan jawi tersebut. Disini masyarakat dan panitia menyiapkan tenda dan mencari air untuk mengaliri sawah yang akan di pakai untuk pacuan jawi. Lalu kerjasama antara pemilik sapid an pemilik sapi lainnya serta saat seorang joki memasak tajak pada sapi pacuannya mereka bekerjasama dengan pemilik sapi untuk memasang tajak kepada jawi tersebut. Kerjasama antara penonton dapat uga kita lihat untuk saling menjaga keamanan dan kenyamanan saat menonton pacuan jawi. Nilai kerjasama dalam pacu jawi dapat dilihat dari dari semua masyarakat, panitia, pemilik sapi, joki dan masyarakat. Nilai ketertiban tercermin pada saat peserta dengan sabar menunggu giliran sapi-sapi pacuan mereka untuk berpacu. Dalam perlombaan pacu jawi ini sapi yang berlomba hanya sepasang-sepasang saja, sehingga peserta yang lain harus menunggu giliran dengan tertib dan sabar. Nilai seni yang tercermin dalam pacuan jawi adalah permainan dari anak Nagari melakukan Tari Piring, Talempong, dan Aguang Bana. Kesenian Tradisional Minangkabau ini mengiringi pacuan jawi tersebut. Hal ini dapat dilihat pada saat music talempong mengiringi tarian piring dan pada saat Niniak mamak berdialog dengan menggunakan Petatah Petitih yang dialunkan sambil berdendang dengan kata-kata penuh makna. Nilai agama yang tercermin dalam pacuan jawi ini adalah ungkapan rasa syukur masyarakat atas hasil panen yang mereka dapatkan. Masyarakat menyadari bahwa semua yang di dapat harus selalu di syukuri.

Sistem pengetahuan dan praktek perawatan jawi pacuan yang dimiliki masyarakat Padang Luar, Kabupaten Tanah Datar.Masyarakat Nagari III Koto khususnya peternak jawi pacuan mereka membuat kandang yang agak berbeda 
dari jawi ternak lainnya. Kalau jawi pacuan kandangnya biasanya di lantai menggunakan bambu, bambu ini disusun dengan serapi-rapinya agar jawi tersebut nyaman dan tidak terkena penyakit rematik. Perawatan jawi pacu ini tidak jauh beda dibandingkan jawi ternak lainnya, yang membedakannya hanyalah jawi pacu ini harus dilatih dan diberi makanan tambahan untuk menunjang dan membuat jawi berkembang begitu cepat. Makanan untuk menunjang pertumbuhannya supaya cepat para peternak menyakini memberi rumput gajah dan daun jagung. Para peternak juga memberi makanan lainnya untuk menambah stamina dan supaya nafsu makannya bertambah dengan membuat ramuan seperti telur bebek atau telur ayam kampung, jahe, madu, gula merah. Semua bahan ini akan dicampurkan ke dalam satu tempat lalu jadilah ramuan untuk menambah stamina jawi tersebut. Untuk latihan jawi pacu ini biasanya dilatih dua atau tiga kali dalam satu minggu. Pertama kali sapi ini dilatih satu persatu disini dibutuhkan kesabaran untuk melatihnya. Latihan pertama kalinya adalah latihan kesabaran disini jawi akan dibawa ke sawah untuk bisa berlari lurus Sampai ujung pematang sawah, jawi ini biasanya dibiarkan dulu untuk mengenal bagaimana lintasan yang akan di lewatinya. Biasanya para peternak juga membawa jawi ini langsung ke tempat tradisi pacu jawi guna untuk menigkatkat mental jawi tersebut. Disini para peternak memiliki cara untuk membuat jawi selalu sehat. Para peternak biasanya memberikan perhatian lebih kepada jawi pacuannya, biasanya sehabis latihan dan tanding jawi-jawi tersebut akan di beri ramuan supaya kondisi jawi tersebut tetap kuat dan sehat, selain memberi ramuan khusus para peternak biasanya mengusuk jawi tersebut sehabis dimandian di pinggiran sawah. Biasanya jawi pacu ini disuntik oleh mantari (dokter hewan) setiap satu bulan sekali supaya tidak terjangkit penyakit, tujua menyuntik ini juga untuk menghilangkan bakteri jahat yang ada pada jawi tersebut. 


\section{Daftar Pustaka}

Aan Komariah dan Djam'an Satori. 2010. Metodologi Penelitian Kualitatif. Bandung: Alfabeta.

Endraswara. 2006. Metode Penelitian Kebudayaan. Yogyakarta: Gadjah Mada University.

Koentjaraningrat. 2009. Pengantar Ilmu Antropologi. Jakarta: PT.Rineka Cipta.

Spradley, James P. 2006. Metode Etnografi. Yogyakarta: PT. Tiara Wacana.

Suzanti, Pernama. 2014. Daya Tarik Pacu Jawi Sebagai Atraksi Wisata Budaya di Kabupaten Tanah Datar. Jurnal Nasional Pariwisata. Vol 6, No. 1, April 2014. 